\title{
ANALISIS KESULITAN GURU DALAM IMPLEMENTASI KURIKULUM 2013 DI KOTA MERAUKE
}

\author{
Markus Palobo' $^{1)}$ dan Yonarlianto Tembang ${ }^{2)}$ \\ ${ }^{1}$ Jurusan Pendidikan Matematika, FKIP, Universitas Musamus \\ ${ }^{2}$ Jurusan Pendidikan Guru Sekolah Dasar, FKIP, Universitas Musamus \\ 1,2Jalan Kamizaun Mopah Lama,Merauke, 99611 \\ E-mail : markuspalobo@unmus.ac.id ${ }^{1)}$,yonartembang@unmus.ac.id ${ }^{2)}$
}

\begin{abstract}
ABSTRAK
Perubahan kurikulum di Indonesia menyebabkan guru harus beradaptasi dengan tuntutan kurikulum yang baru. Kurikulum 2013 yang diterapkan di Indonesia saat ini tidak berjalan dengan lancar sesuai dengan harapan pemerintah. Salah satu yang menjadi kendala implementasi kurikulum 2013 adalah kesulitan guru dalam menyiapkan perangkat pembelajaran sesuai kurikulum baru. Penelitian ini bertujuan untuk mendeskripsikan kesulitan yang dialami oleh guru sekolah menengah pertama dalam mengembangakan perangkat pembelajaran berdasarkan kurikulum 2103, serta untuk mengetahui faktor-faktor yang menyebabkan kesulitan, dan solusi untuk mengatasi kesulitan tersebut. Jenis penelitian ini merupakan penelitian deskriptif kualitatif. Subjek penelitian adalah kepala sekolah dan guru di kota merauke yang berasal dari 20 sekolah dasar, 12 sekolah menengah pertama dan 8 sekolah menengah atas se-kota merauke. Teknik pengumpulan data dilakukan dengan penyebaran angket, wawancara dan dokumentasi perangkat pembelajaran guru. Analisis data dalam penelitian ini meliputi reduksi data, penyajian data dan penarikan kesimpulan. Hasil penelitian diperoleh bahwa guru di kota Merauke mengalami kesulitan dalam mengembangakan perangkat pembelajaran berdasarkan kurikulum 2013. Kesulitan-kesulitan guru antara lain dalam (1) pengembangan indikator pencapaian kompetensi, (2) penyusunan skema pencapaian kompetensi dasar, (3) pengembangan kegiatan apersepsi, (4) pengembangan aktivitas kegiatan inti, (5) perancangan kegiatan menarik kesimpulan, dan (6) penyusunan penilaian. Penelitian menyimpulkan bahwa guru masih memerlukan pelatihan pengembangan perangkat kurikulum 2013 khususnya pada penyusunan rencana pelaksanaan pembelajaran.
\end{abstract}

Kata Kunci: Pengembangan, Implementasi, Kurikulum 2013, Kesulitan Guru, Merauke

\section{PENDAHULUAN}

Pembelajaran di sekolah secara umum terdiri atas tiga tahapan penting, yakni perencanaan, pelaksanaan dan evaluasi. Ketiga tahapan tersebut saling berkaitan satu sama lain dalam membentuk kegiatan pembelajaran yang ideal. Kegiatan perencanaan merupakan tahapan awal dalam suatu pembelajaran di sekolah yang wajib dilaksanakan oleh seorang pendidik atau guru. Tahap perencanaan menjadi patokan dalam pelaksanaan dan evaluasi pembelajaran, sehingga perlu dipersiapkan dengan sebaik mungkin untuk keberhasilan pembelajaran. Proses perencanaan, pelaksanaan dan evaluasi merupakan bagian dari suatu kurikulum pada satuan pendidikan.

Indonesia saat ini telah mengalami sebelas kali perubahan bentuk kurikulum pendidikan, untuk menyempurnakan kurikulum sehingga dapat menjawab tuntutan kebutuhan masyarakat Indonesia. Saat ini kurikulum yang diterapkan pada tingkat satuan pendidikan dasar hingga menengah adalah kurikulum 2013 yang telah mengalami revisi pada tahun 2016 dan wajib diterapkan oleh semua sekolah di Indonesia. Dalam bentuk kurikulum apapun, kegiatan perencanaan pembelajaran tetap menjadi bagian terpenting dari kegiatan pembelajaran. Pada kurikulum 2013 guru dalam proses perencanaan dituntut untuk menyusun rencana pelaksanaan pembelajaran, lembar kegiatan siswa, serta instrumen penilaian.

Penyusunan rencana pelaksanaan pembelajaran oleh guru, meskipun sudah menjadi rutinitas tiap semester dalam pembelajaran, namun tidak semua rencana pelaksanaan pembelajaran yang telah disusun oleh guru sesuai dengan ketentuan kurikulum yang berlaku. Pada kurikulum 2013 yang menekankan pada pendekatan saintifik, yang dikenal dengan istilah $5 \mathrm{M}$ (Mengamati, Menanya, Menalar, Mencoba, dan Mengomunisasikan). Rencana Pelaksanaan Pembelajaran yang dihasilkan oleh guru terkadang menampilkan komponen dari pendekatan saintifik (5M) hanya untuk memenuhi tuntutan dari kurikulum 2013, namun makna dari pendekatan tersebut masih belum sesuai dengan yang dimaksud oleh kurikulum. Misalnya saja pada kegiatan mengamati, biasanya dalam rencana pelaksanaan pembelajaran kegiatan mengamati selalu dituliskan dengan menyatakan siswa mengamati materi pada buku pelajaran. Hal ini tidak salah sepenuhnya, namun mengamati yang tepat sebaiknya dengan menyiapkan objek tertentu dapat berupa lingkungan, gambar atau 
video atau ilustrasi yang berkaitan dengan topik pembelajaran untuk diamati oleh siswa, dengan harapan dari hasil mengamati tersebut akan memunculkan pertanyaan dari siswa. Namun untuk menyiapkan objek yang kan diamati tersebut bukanlah perkara mudah, karenanya perlu persiapan dan referensi yang luas. Hal tersebut menunjukkan bahwa tidaklah mudah tugas seorang guru dalam menyusun rencana pelaksanaan pembelajaran.

Permasalahan guru dalam kurikulum 2013 tidak hanya sebatas pada penyusunan rencana pelaksanaan pembelajaran. Permasalahan guru dalam mengimplementasikan kurikulum 2013 meliputi permasalahan guru dalam pencapaian standar-standar isi, proses, kelulusan dan standar penilaian. Hasil penelitian Maisyaroh dan kawan-kawan diperoleh bahwa guru menghadapi masalah dalam pencapaian standar proses, yaitu: guru merasa kesulitan menyusun dan mengembangkan RPP, mengembangkan indikator yang sesuai dengan kompetensi dasar; guru tidak memahami penerapan pendekatan saintifik dalam pembelajaran; guru kesulitan mengimplementasikan pembelajaran konstruktifistik; guru merasa kesulitan dalam menentukan media pembelajaran terutama yang berbasis informasi teknologi (laptop dan LCD); guru merasa kesulitan dalam pembagian waktu untuk remidi(Maisyaroh et al., 2014). Guru merupakan faktor yang mempengaruhi berhasil tidaknya proses belajar oleh karena itu guru harus menguasai prinsip-prinsip belajar dan guru harus menciptakan suatu kondisi belajar yang sebaik-baiknya bagi siswa(Ahmad, 2013)

Permasalahan guru dalam menyusun rencana pelaksanaan pembelajaran dapat disebabkan oleh kurangnya pemahaman guru tentang kurikulum 2013. Hasil penelitian Ika Krisdiana, Davi Apriandi dan Reza Kusuma Setiansyah diperoleh bahwa dalam pemahaman terhadap kurikulum 2013, guru mengalami kesulitan pada memahami tujuan kurikulum 2013(I. Krisdiana and Setiansyah, 2014). Lebih dari $40 \%$ guru merasa kurang paham terkait hal itu. Lebih lanjut hasil penelitian mengungkapkan bahwa penyebabnya karena berbagai hal yakni, kurang aktifnya guru dalam mencari informasi/referensi terkait kurikulum 2013, kurangnya pelatihan atau workshop yang diikuti, sehingga pemahaman dalam implementasi kurikulum 2013 masih kurang (Darnius, 2016).

Sekolah-sekolah di kota Merauke telah menerapkan kurikulum 2013 sejak tahun 2015. Dalam pelaksanaan kurikulum 2013 tersebut tentunya setiap guru telah melaksanakan kegiatan penyusunan rencana pelaksanaan pembelajaran dan perangkat penilaian serta lembar kegiatan siswa. Dalam proses penyusunan perangkat perencaan pembelajaran tersebut, guru-guru didampingi oleh pakar dan praktisi kurikulum 2013. Meskipun demikian, guru-guru di Merauke tetap mengalami beberapa kendala dalam pelaksanaan kurikulum 2013, tidak terkecuali dalam hal penyusunan rencana pelaksanaan pembelajaran. Dalam suatu kegiatan workshop bersama dengan guru-guru di merauke, yang diantaranya terdapat beberapa guru, teramati bahwa masih terdapat perbedaan-perbedaan persepsi antar guru mengenai rencana pelaksanaan pembelajaran. Perbedaan tersebut seperti pada format rencana pelaksanaan pembelajaran, pada langkah-langkah pembelajaran, maupun dalam hal penilaian (Indonesia, 2013). Tidak sedikit juga guru yang menggunakan rencana pelaksanaan pembelajaran hasil karya guru lain baik yang diperoleh dari internet maupun yang diperoleh dari rekan guru sebidang.

Permasalahan guru dalam implementasi kurikulum 2013 terjadi secara masif diseluruh Indonesia. Hasil penelitian federasi serikat guru indonesia di 10 provinsi indonesia diperoleh bahwa terdapat sejumlah masalah krusial dan kegagalan sistematik pelatihan persiapan guru. Pelatihan untuk merubah pendekatan guru dalam pembelajaran dari pendekatan tradisional menjadi pendekatan scientific tidak mudah dan butuh waktu yang bertahun-tahun untuk belajar dan membiasakan diri (Indonesia, 2005). Perubahan juga terjadi pada waktu jam pelajaran serta adanya penghapusan mata pelajaran, sehingga guru akan mengalami kesulitan untuk dapat beradaptasi dengan kurikulum terbaru.

Penerapan pendekatan scientific dalam kurikulum 2013 belum sepenuhnya dipahami dan dapat diterapkan dengan tepat oleh guru. Hasil penelitian said darnius menemukan bahwa guru kesulitan dalam menalar dan mengkomunikasikan. Guru cenderung tidak mendorong siswa untuk berusaha menemukan sendiri pengetahuan baru dari apa yang dipelajari. Selain itu siswa belum terbiasa dalam kegiatan mengkomunikasikan, sehingga kegiatan tersebut tidak berjalan lancar (Puskurbuk., 2012).

Beberapa hasil penelitian menunjukkan bahwa masih terdapat kendala dan kesulitan dalam implementasi kurikulum 2013 baik dalam hal persiapan, pelaksanaan, maupun dalam hal penilaian. Peneliti memilih aspek persiapan sebagai bagian yang paling urgen untuk diidentifikasi sebagai bahan untuk perbaikan dalam pelaksanaan dan penilaian. Kemampuan guru dalam menyiapkan perencanaan berupa menyusun rencana pelaksanaan pembelajaran, lembar kegiatan siswa dan instrumen penilaian sangat penting untuk keberhasilan pelaksanaan pembelajaran. Karenanya itu maka perlu diidentifikasi kesulitan-kesulitan apa saja yang dialami oleh guru dalam proses menyusun rencana pelaksanaan pembelajaran serta perangkatnya yang dapat dijadikan bahan tindak lanjut perbaikan persiapan pembelajaran. Atas dasar tersebut maka peneliti melaksanakan penelitian untuk mendeskripsikan kesulitan-kesulitan guru dalam menyusun perangkat pembelajaran berdasarkan kurikulum 2013. Penelitian dilaksanakan pada guru-guru sekolah dasar dan sekolah menengah di kota Merauke. 


\section{RUANG LINGKUP}

Rumusan masalah dalam penelitian ini adalah: Kesulitan apa saja yang dialami oleh guru-guru di kota merauke dalam mengembangkan perangkat pembelajaran kurikulum 2013. Kesulitan guru yang dimaksud adalah kesulitan dalam menyusun rencana pelaksanaan pembelajaran berdasarkan kurikulum 2013 serta kesulitan dalam implementasi pembelajaran di di kelas berdasarkan kurikulum 2013.

\section{BAHAN DAN METODE}

Pada bagian ini dibagi atas dua yakni bahan kajian atau kajian teori dan metodologi penelitian.

\subsection{Bahan Kajian}

Bahan kajian dalam penelitian ini meliputi kajian tentang kesulitan guru, kajian tentang kurikulum 2013, dan kajian tentang kesulitan guru dalam pengembangan perangkat kurikulum 2013

\section{Kesulitan Guru}

Undang-undang No. 14 Tahun 2005 tentang Guru dan Dosen menjelaskan bahwa guru adalah pendidik profesional dengan tugas utama mendidik, mengajar, membimbing, mengarahkan, melatih, menilai, dan mengevaluasi peserta didik pada pendidikan anak usia dini jalur pendidikan formal, pendidikan dasar, dan pendidikan menengah (Indonesia, 2005). Guru yang profesional harus mengetahui kondisi, arah, nilai, tujuan, dan kualitas suatu keahlian dan kewenangan dalam bidang pendidikan dan pengajaran yang berkaitan dengan pekerjaan. Guru yang profesional akan tercermin dalam pelaksanaan pengabdian tugas-tugas yang ditandai dengan keahlian baik dalam materi pembelajaran maupun metode pembelajaran.

Perubahan paradigma penyelenggaran pendidikan menjadikan peran guru semakin kompleks, karena tuntutan kepada guru tidak sekedar mengajar dan mendidik para siswa didepan kelas dan kegiatan lainnya dalam melaksanakan ekstrakurikuler, guru juga diharapkan mampu menjadi sebagai fasilitator dan mediator sehingga peran guru menjadi lebih banyak. Pembaharuan kurikulum 2013 yang mampu mengembangkan dan meningkatkan mutu pendidikan yang ada di Negara ini. Upaya pembaharuan dilakukan secara besar-besaran Kurikulum KTSP diperbaharui dengan Kurikulum 2013. Sesuai dengan Perpres Nomor 5 Tahun 2010 tentang rencana pembanguanan jangka menengah nasional, pemerintah mengagendakan aksi terkait dengan kurikulum berupa penataan dan penyempuranaan kurikulum yang ada

\section{Kurikulum 2013}

Peningkatan sumberdaya manusia merupakan tujuan setiap bangsa, untuk mencapai tujuan tersebut dapat dilaksanakan dengan berbagai cara di antaranya melalui pendidikan. Pendidikan dikembangkan terus menerus seiring dengan perkembangan ilmu pengetahuan, teknologi, dan seni. Upaya perbaikan kualitas pendidikan yang terus-menurus ini diwujudkan dalam bentuk perubahan kurikulum. Perubahan kurikulum ini telah dilaksanakan oleh berbagai negara-negara besar diantaranya adalah Korea, Eropa, Hongkong, China, Turki, Pakistan dan Indonesia.

Pemerintah Indonesia memberlakukan kurikulum baru untuk pendidikan di sekolah dasar dan menengah pada tahun 2013. Kurikulum ini bertujuan untuk meningkatkan kualitas sumberdaya daya manusia dan meningkatkan daya saing dalam dunia pendidikan (Puskurbuk., 2012), mengemukakkan bahwa kurikulum ini dapat memberikan harapan yang dapat menghasilkan sumber daya manusia yang produktif, kreatif, inovatif dan afektif, melalui penguatan kompetensi sikap, pengetahuan, dan keterampilan. Tujuan ini dilakukan dengan merubah pradigma belajar ke kontruktivisme dari siswa menerima materi menjadi siswa membentuk pemahaman konsep dalam mata pelajaran sendiri, dengan menggunakan penilaian berbasis kompetensi, dan penilaian kelas secara otentik.

Muatan pada tiap mata pelajaran yang dipelajari siswa meliputi 4 kompetensi inti, yaitu kompetensi sikap sosial, sikap spritual, pengetahuan, dan keterampilan (Indonesia, 2013). Masing-masing kompetensi kemudian dijabarkan menjadi beberapa kompetensi dasar yang dikembangkan berdasarkan pada prinsip akumulatif, saling memperkuat (reinforced), dan memperkaya (enriched) antar mata pelajaran dan jenjang pendidikan (organisasi horizontal dan vertikal). Kompetensi dasar dirumuskan untuk mencapai kompetensi inti. Rumusan kompetensi dasar dikembangkan dengan memperhatikan karakteristik peserta didik, kemampuan awal, serta ciri dari suatu mata pelajaran tersebut. Hal ini yang membedakan kurikulum 2013 dengan kurikulum yang berlaku sebelumnya. Penekanan bukan hanya pada kompetensi kognitif saja, namun juga pada kompetensi sikap dan keterampilan yang menjadi hal penting untuk dipelajari dan diberikan kepada siswa.

Proses pembelajaran digunakan berupa paradigma konstruktivisme yaitu dengan melakukan rekomendasi pembelajaran dengan pendakatan saintifik, pembelajaran berbasis masalah atau pembelajaran berbasis projek (Indonesia, 2013). Sintaks pembelajaran pun telah ditetapkan sesuai dengan harapan dan dapat mempermudah guru dalam melakasankan pembelajaran, dengan pembelajaran ini, siswa menjadi lebih aktif dan mengkonstruk pemahaman diri sendiri. Asesmen pada kurikulum 2013 yang diterapkan adalah penilaian autentik. Penilaian auntentik merupakan proses penilaian secara global untuk melakukan penilaian secara mendalam melalui pemikiran, motivasi, atau suatu tindakan. Dalam penilaian ini siswa diharapkan berfikir kritis, menganalisis informasi, memperoleh ide yang baru, mengomunikasikan, kerjasama, memecahkan masalah, dan menyimpulkan (DiMartino, Castameda and Miles, 2007). Pada asesmen autentik ini, kompentesi siswa dinilai, baik pengetahuan, keterampilan, sikap atau 
kombinasi dari ketiga (Gulikers, Bastiaens and Kirschner, 2004).

Sebelum kurikulum ini dilaksanakan, hal yang penting untuk diperhatikan adalah bagaimana cara menyusun suatu perangkat pembelajaran yang dapat diimplementasikan kedalam pembelajaran. Ketika kurikulum baru diberlakukan, tentu ada hambatan untuk mengimplementasikannya. Hambatan dan tantangan yang dialami dan dihadapi banyak guru yakni tahap implementasi, misalnya tambahan tugas guru yang berat dan perbedaan-pebadaaan dala kelas yang dialami selama pembelajaran (Cheung and Wong, 2016), kekurangan pemahaman guru mengenai kurikulum tersebut. pembelajaran dengan pendekatan konstruktivisme tidak langsung berjalan lancar seperti yang diharapkan. Pada pelaksanaan pembelajaran yang melibatkan kehidupan nyata, lingkungan belajar tidak berorientasi pada kehidupan nyata, lingkungan belajar tidak terkait dengan pengalaman belajar siswa, yang menyebabkan pendekatan kontruktivisme kurang efisien dan siswa kurang memperoleh otonomi belajar secara layak (Eraslan, 2013)

3. Kesulitan guru dalam mengembangkan perangkat pembelajaran

Kesulitan guru dalam menyusun perangkat pembelajaran merupakan suatu masalah yang seringkali dihadapi dalam kehidupan pembelajaran para guru. banyaknya kendala dalam penyusunan ini menyebabkan guru menjadi malas untuk membuat perangkat pembelajaran. Padahal pada kurikulum 2013 mengharuskan guru wajib membuat dan menyusun perangkat pembelajaran. Kesulitan guru dalam merencanakan pembelajaran merupakan bagian dari dampak kekurangpahaman guru terhadap kurikulum. Kekurangpahaman ini menyebabkan guru kesulitan mendasin pembelajaran saintifik atauoun pendekatan yang disesuaikan dengan kurikulum, kesulitan merencanakan peniliaian, kesulitan merencanakan penilaian, dan kesulitan menyusun instrumen penilaian sikap. Kesulitan-kesulitan guru tersebut senada dengan hasil penelitian Lumadi (Lumadi, 2013).

Permasalahan guru dalam menyusun rencana pelaksanaan pembelajaran dapat disebabkan oleh kurangnya pemahaman guru tentang kurikulum 2013. Pemahaman terhadap kurikulum 2013, guru mengalami kesulitan pada memahami tujuan kurikulum 2013. Lebih dari $40 \%$ guru merasa kurang paham terkait hal itu. Lebih lanjut hasil penelitian mengungkapkan bahwa penyebabnya karena berbagai hal yakni, kurang aktifnya guru dalam mencari informasi/referensi terkait kurikulum 2013, kurangnya pelatihan atau workshop yang diikuti, sehingga pemahaman dalam implementasi kurikulum 2013 masih kurang (I. Krisdiana and Setiansyah, 2014)

Guru merupakan faktor yang mempengaruhi berhasil tidaknya proses belajar oleh karena itu guru harus menguasai prinsip-prinsip belajar dan guru harus menciptakan suatu kondisi belajar yang sebaik-baiknya bagi siswa (Surya., Witjaksono and Utomo, 2016). Penerapan pendekatan scientific dalam kurikulum 2013 belum sepenuhnya dipamahi dan dapat diterapkan dengan tepat oleh guru. Guru kesulitan dalam menalar dan mengkomunikasikan dan cenderung tidak mendorong siswa untuk berusaha menemukan sendiri pengetahuan baru dari apa yang dipelajari. Selain itu siswa belum terbiasa dalam kegiatan mengkomunikasikan, sehingga kegaiatan tersebut tidak berjalan lancar (Darnius, 2016)

\subsection{Metode Penelitian}

Penelitian ini merupakan penelitian deskriptif kualitatif. Penelitian deskriptif merupakan penelitian yang digunakan untuk menganalisis data dengan cara mendeskripsikan atau menggambarkan data yang telah terkumpul sebagaimana adanya tanpa bermaksud membuat kesimpulan yang berlaku untuk umum atau generalisasi (Palobo and Tembang, 2019) Penelitian dilaksanakan bagi guru-guru di kota Merauke yang berjumlah 40 sekolah dengan satu sekolah diwakili satu guru. Subjek yang akan diteliti sebanyak 40 orang. Pemilihan subjek yang akan diteliti dalam penelitian ini didasarkan pada pertimbangan bahwa masih terdapat beberapa guru baru yang belum pernah menyusun rencana pelaksanaan pembelajaran ataupun belum memiliki pengalaman yang cukup untuk dapat diperoleh informasi yang dibutuhkan. Semua subjek telah memiliki pengalaman lebih dari 5 tahun mengajar dan menyusun perangkat pembelajaran baik menurut kurikulum 2013 maupun berdasarkan kurikulum sebelumnya (KTSP dan KBK).

Instrumen penelitian ialah angket kesulitan guru menyusun rencana pelaksanaan pembelajaran yang bersifat pernyataan terbuka dan tertutup. Angket terdiri atas 3 bagian utama, bagian pertama berkaitan dengan komponen dan sistematika rencana pelaksanaan pembelajaran, bagian kedua tentang pengembangan rencana pelaksanaan pembelajaran, dan bagian terakhir berkaitan dengan aspek pelaksanaan kurikulum 2013. Angket terdiri atas 38 pertanyaan terbuka, 40 pertanyaan tertutup serta 1 soal bersifat gabungan pernyataan tertutup dan terbuka.

Teknik pengumpulan data dalam penelitian adalah melalui, pembagian angket, wawancara dan dokumentasi. Penyebaran angket dilaksanakan dengan membagikan angket kesulitan penyusunan rencana pelaksanaan pembelajaran secara langsung kepada 40 subjek penelitian sekaligus menjelaskan tujuan dan petunjuk pengisian angket. Wawancara dilakukan terhadap kepala sekolah dan beberapa guru berdasarkan jawaban guru terhadap angket yang diberikan. Dokumentasi dilakukan dalam bentuk mengamati secara langsung ketersediaan perangkat pembelajaran berupa rencana pelaksanaan pembelajaran, lembar kegiatan siswa dan instrumen penilaian. 
Data yang diperoleh dalam penelitian ini adalah data kualitatif berupa data pernyataan pribadi dari subjek penelitian berkaitan dengan pertanyaan terbuka yang diberikan dalam angket serta data kategori untuk jawaban terhadap pertanyaan tertutup. Data kategori terdiri atas dua macam yakni kategori setuju dan tidak setuju serta ketegori tingkat kesulitan.

Teknik analisis data dalam penelitian ini terdiri atas tiga tahap analisis data model miles dan huberman yaitu reduksi data, penyajian data, dan penarikan kesimpulan dan verifikasi (Palobo and Tembang, 2019). Reduksi data dalam proses ini peneliti melakukan pengumpulan data dengan responden melalui observasi dan angket. Penyajian data dilakukan dengan menuliskan data hasil angket dan observasi dalam bentuk kategori-kategori. Sedangkan kegiatan penarikan kesimpulan dan verifikasi peneliti melakukan perbandingan hasil angket dengan observasi dan menarik kesimpulan. Secara garis besar prosedur penelitian terdiri atas tiga langkah yakni persiapan, pelaksanaan dan analisis data

\section{PEMBAHASAN}

Pembahasan dalam penelitian ini disajikan secara terpisah yakni deskripsi kesulitan guru dan ulasan kesulitan guru berdasarkan hasil penelitian.

\subsection{Deskripsi Kesulitan Guru}

1. Komponen dan Sistematika Rencana Pelaksanaan Pembelajaran

Pada komponen dan sistematika rencana pelaksanaan pembelajaran terdiri atas 3 pertanyaan besar. Pada pertanyaan tentang kesesuaian rencana pelaksanaan pembelajaran yang disusun oleh guru dengan sistematika yang ditentukan dalam kurikulum 2013, diperoleh bahwa seluruh guru di Merauke telah menyusun Rencana Pelaksanaan Pembelajaran sesuai dengan sistematika yang telah ditetapkan dalam kurikulum 2013, karena seluruh guru telah mengikuti pelatihan penyusunan perangkat kurikulum 2013. Guru Merauke telah mengikuti workshop kurikulum 2013 dalam kurung waktu 3 tahun terakhir yang umumnya dilaksanakan setiap awal semester. Pemateri dalam setiap workshop kurikulum 2013 merupakan para ahli kurikulum 2013 baik dari tingkat provinsi maupun utusan dari pemerintah pusat. Hasil pengamatan pada dokumen rencana pelaksanaan pembelajaran yang dimiliki oleh setiap guru teramati bahwa secara umum sudah sesuai dengan sistematika yang diatur dalam peraturan menteri kebudayaan.

Pada pertanyaan kedua tentang tingkat kesulitan dalam menyusun 20 komponen rencana pelaksanaan pembelajaran diperoleh bahwa menurut guru mengategorikan sangat mudah dalam menyusun komponen identitas sekolah, kompetensi inti, kompetensi dasar, kegiatan pembuka pembelajaran, dan kegiatan penutupan pembelajaran. Komponen-komponen tersebut relatif sama dengan model rencana pembelajaran kurikulum sebelumnya, sehingga guru berpendapat bahwa komponen tersebut masih sangat mudah untuk disusun. Kompetinsi inti dan kompetensi dasar merupakan komponen dari rencana pelaksanaan pembelajaran yang sudah ditetapkan secara nasional, sehingga guru tidak perlu lagi menyusunnya, melainkan tinggal digunakan.

Hasil penelitian menunjukkan bahwa guru mengategorikan komponen uraian materi, media/alat pembelajaran, sumber belajar, banyaknya pertemuan, alokasi waktu pembelajaran, kegiatan apersepsi, kegiatan saintifik, lembar kerja siswa, mengarahkan siswa ketujuan pembelajaran, teknik penilaian secara umum oleh para guru dianggap memiliki tingkat kesulitan pada kategori sedang untuk disusun dalam rencana pelaksanaan pembelajaran. Kegiatan saintifik merupakan bagian terpenting dalam kurikulum 2013 yang lebih dikenal guru sebagai 5M. Dalam revisi kurikulum 2013 pada tahun 2016 tidak memberikan urutan yang mutlak dalam kegiatan 5M. Sedangkan untuk komponen lainnya sudah familiar bagi para guru, sehingga tingkatan kesulitan yang dialami oleh guru merupakan akumulasi dari kurikulum sebelumnya.

Komponen dari rencana pelaksanaan pembelajaran yang masuk kategori sulit bagi guru di Merauke untuk disusun adalah indikator pencapaian kompetensi, pendekatan/metode/strategi pembelajaran, instrumen penilaian, remedial, dan pengayaan. Kelima komponen tersebut belum terdapat dalam kurikulum sebelumnya sehingga menjadikan komponen tersebut cukup sulit bagi guru. Dalam kurikulum 2013 indikator pencapaian kompetensi belum ditentukan oleh pemerintah, sehingga setiap guru harus mengembangkan sendiri indikator pencapaian kompetensi berdasarkan kompetensi dasar. Atas dasar itulah para guru Merauke merasa kesulitan dalam menyusun indikator pencapain kompetensi dalam rencana pelaksanaan pembelajaran. Pemilihan metode/strategi pembelajaran tidak mudah untuk dilaksanakan karena perlu memperhatikan materi ajar serta mempertimbangkan karakter siswa yang harus didukung oleh sumber daya disekolah tersebut. Kurikulum 2013 dalam penilaian tidak hanya pada aspek kognitif, tapi juga adanya penilaian terhadap aspek afektif dan psikomotorik siswa. Penilaian ketiga aspek tersebut memerlukan instrumen penilaian yang harus disusun sendiri oleh guru sesuai dengan materi ajar dalam rencana pelaksanaan pembelajaran. Bagi guru penyusunan instrumen penilaian menjadi bagian yang sulit untuk dikembangkan mengingat selama ini guru sudah terbiasa hanya menyusun instrumen penilaian aspek pengetahuan. Sama halnya dengan instrumen penilaian, komponen remedial dan pengayaan menjadi bagian yang baru dalam rencana pelaksanaan pembelajaran kurikulum 2013. Pembelajaran remedial dan pengayaan dilaksanakan untuk kompetensi pengetahuan dan keterampilan. Pembelajaran remedial diberikan kepada siswa yang belum mencapai atau melampaui KBM. Sedangkan pembelajaran pengayaan 
diberikan segera setelah siswa diketahui telah mencapai KBM berdasarkan penilaian harian. Pembelajaran pengayaan diberikan hanya sekali dan tidak diakhiri dengan penilaian.

Pertanyaan terakhir pada komponen dan sistematika rencana pelaksanaan pembelajaran yang perlu dan tidak perlu diperoleh hasil bahwa secara umum guru menganggap bahwa 20 komponen dari rencana pelaksanaan pembelajaran diperlukan. Namun terdapat guru yang menganggap komponen kompetensi inti dan uraian materi tidak diperlukan dalam rencana pelaksanaan pembelajaran. Menurut salah satu guru di Merauke, uraian materi tidak diperlukan, cukup dengan menuliskan judul materinya ajar, sedangkan materi ajar dapat diperoleh guru dari buku atau dengan menyusun materi dalam power point. Selain itu terdapat juga guru yang berpendapat bahwa kegiatan saintifik dalam kegiatan inti tidak harus dituliskan secara detail, cukup skemanya saja karena akan terlalu luas jika dituliskan.

Catatan refleksi guru mengenai sistematika dan komponen rencana pelaksanaan pembelajaran kurikulum 2013 memberikan penekanan pentingnya penyusunan rencana pelaksanaan pembelajaran sesuai dengan peraturan sehingga mempermudah guru dalam menggunakan, baik oleh guru itu sendiri maupun oleh guru lain. Terdapat juga guru yang berpendapat bahwa diperlukan bimbingan secara berkelanjutan bagi guru dalam penyusunan perangkat pembelajaran, sehingga guru tidak lagi menyalin perangkat guru lain namun betul-betul menggunakan perangkat hasil buatan sendiri. Pengembangan Rencana Pelaksanaan Pembelajaran Kurikulum 2013

Bagian kedua dari angket kesulitan guru dalam penyusunan rencana pelaksanaan pembelajaran adalah tentang pengembangan rencana pelaksanaan pembelajaran. Pada bagian ini peneliti berusaha menggali pemahaman guru tentang indikator kompetensi dasar, skema pencapaian kompetensi, materi apersepsi, pembelajaran inti, dan strategi menutup pelajaran. Semua guru Di kota Merauke sudah memahami perbedaan indikator pembelajaran dengan kompetensi dasar. Tentang dasar penyusunan indikator pembelajaran, para guru telah sepakat bahwa kompetensi dasar merupakan dasar penyusunan indikator pembelajaran. Menurut guru indikator harus mengakomodir karakter mata pelajaran sehingga menggunakan kata kerja operasional yang sesuai. Selain itu dinyatakan bahwa indikator merupakan dasar untuk membuat alat penilaian. Pada pertanyaan tujuan penyusunan indikator pencapaian kompetensi dasar beberapa guru menyatakan bahwa untuk mempermudah guru mencapai kompetensi dasar. Selain itu pendapat lain menyatakan bahwa agar mudah mengetahui tujuan pembelajaran dan menentukan materi ajar. Kendala yang dialami guru ketika menyusun indikator pembelajaran kompetensi dasar adalah kesulitan dalam pemilihan kata-kata operasional yang tepat. Guru juga kesulitan dalam menjabarkan indikator sesuai dengan tingkat kepentingannya apakah itu urgen atau penunjang. Guru agama dan Budi Pekerti mengaku kesulitan menyusun indikator penilaian sikap agar dapat dipertanggungjawabkan.

Pada penyusunan skema pencapaian kompetensi, guru secara umum mendefinisikan skema pencapaian kompetensi sebagai kerangka acuan atau garis besar yang harus dicapai oleh siswa. Bagi guru IPA skema pencapain kompetensi sama dengan peta konsep. Hubungan antara skema pencapaian kompetensi menurut guru bahwa skema pencapaian indikator merupakan langkah yang ditempuh dalam pembelajaran untuk mencapai kompetensi yang dirinci dalam indikator pencapaian kompetensi dasar. Selain itu beberapa guru menyatakan bahwa skema pencapain dan indikator pencapaian sama-sama mengarah pada pencapaian kompetensi dasar. Menurut guru tujuan menyusun skema pencapaian kompetensi adalah sebagai arah dalam proses pembelajaran. Selain itu agar materi yang disampaikan berkesinambungan. Pada pertanyaan bagaimana guru menyusun uraian materi dalam rencana pelaksanaan pembelajaran, sebagian besar guru menyatakan bahwa materi pokok dilihat guru dari silabus kemudian dikembangkan dari sumber buku-buku penunjang dengan selalu mengacu pada indikator. Terdapat juga guru yang berpendapat bahwa uraian materi harus disusun dari yang paling mudah hingga materi yang paling sulit. Selanjutnya peneliti menanyakan bagaimana guru memilih pendekatan/metode/strategi pembelajaran. Menurut guru Di kota strategi pembelajaran menyesuaikan antara materi dengan situasi dan kondisi siswa dalam proses mengajar dengan memperhitungkan ketercapaian tujuan pembelajaran. Selain itu guru harus memilih strategi pembelajaran agar materi yang disampaikan mudah dipahami oleh peserta didik. Kesulitan yang dialami oleh guru Di kota dalam menyusun skema pencapaian kompetensi dasar antara lain kesulitan dalam menganalisis konsep materi yang harus diselaraskan dengan pendekatan yang digunakan, kesulitan dalam menentukan metode yang sesuai dengan materi ajar, sarana dan prasarana untuk menunjang skema pencapaian kompetensi dasar, tingkat kemampuan siswa yang berbeda-beda, kesulitan dalam penilaian yang sesuai untuk mengukur ketercapaian tujuan pembelajaran.

Bagian berikutnya pada angket tentang pengembangan rencana pelaksanaan pembelajaran peneliti menanyakan tentang apersepsi. Apersepsi menurut guru adalah kegiatan pendahuluan dalam proses pembelajaran yang bertujuan untuk memberikan motivasi belajar kepada peserta didik agar proses pembelajaran dapat berjalan maksimal. Apersepsi merupakan motivasi bagi peserta didik tentang pentingnya mempelajari materi yang akan dibahas. Namun beberapa guru mengartikan apersepsi sebagai penghargaan yang diberikan kepada siswa terhadap suatu karya yang dibuat oleh siswa. Berkaitan dengan hubungan antara skema pencapaian kompetensi dengan materi apersepsi menurut guru materi apersepsi 
membuka wawasan, pikiran, dan memancing pengetahuan peserta didik untuk mencapai kompetensi. Sedangkan pendapat lainnya menyatakan bahwa materi apersepsi harus dituangkan dalam skema pencapaian kompetensi. Cara guru dalam menyusun kegiatan apersepsi berbeda-beda. Salah satu guru menyatakan bahwa perlu meninjau kembali materi yang sudah dipelajari, kemudian membandingkan pengetahuan lama dengan yang akan disajikan, kemudian menjelaskan konsep dan memberi motivasi. Terdapat juga guru yang berpendapat bahwa dalam menyusun apersepsi, perlu melakukan pengamatan dan observasi kemudian menentukan pendekatan apersepsi. Pemilihan strategi pelaksanaan apersepsi oleh guru disesuaikan dengan materi yang akan diajarkan, selain itu menurut salah satu guru di kota Merauke, kita harus memilih apersepsi yang dapat membangkitkan semangat peserta didik sehingga timbul rasa senang dan tertantang untuk mempelajari topik yang akan dipelajari. Kesulitan-kesulitan yang dialami oleh guru dalam mengembangkan kegiatan/materi apersepsi antara lain kesesuaian antara materi yang akan dipelajari dengan apersepsinya. Kesulitan lainnya adalah dalam mengukur pengetahuan dasar peserta didik, selain itu guru terkadang belum menguasai secara baik strategi pembelajaran yang dipilih.

Pengembangan aktivitas pembelajaran inti merupakan bagian terpenting dalam rencana pelaksanaan pembelajaran kurikulum 2013. Menurut sebagian besar guru Di kota Merauke, pembelajaran inti merupakan kegiatan utama yang dilaksanakan oleh guru dalam proses belajar mengajar. Pembelajaran inti merupakam suatu proses yang paling penting yang dirancang untuk mencapai kompetensi dasar. Hal-hal yang dipertimbangkan oleh para guru dalam pengembangan aktivitas pembelajaran inti adalah waktu, metode, situasi siswa dan tujuan yang ingin dicapai. Pendapat lain mempertimbangkan ruang lingkup, kerumitan, keluasan, kesediaan pendukung, buku dan alat peraga. Berkenaan dengan lembar kerja siswa (LKS), secara umum guru setuju bahwa lembar kerja siswa diperlukan dalam pembelajaran inti karena dengan LKS siswa menjadi terlibat langsung dalam pembelajaran secara aktif. Selain itu menurut guru LKS digunakan untuk mengukur kemampuan peserta didik. Kecuali untuk guru pendidikan jasmani menyatakan bahwa LKS tidak perlu, karena pembelajaran bersifat praktikum. Pada kegiatan inti, pemilihan pendekatan/strategi/metode pembelajaran dilakukan menyesuaikan dengan tujuan pembelajaran dan kompetensi yang ingin dicapai. Materi ajar, situasi siswa dan kondisi kelas juga menjadi pertimbangan guru dalam memilih strategi pembelajaran inti. Guru di kota Merauke akan memilih metode yang dapat meningkatkan motivasi dan kreativitas siswa. Kesulitan yang dialami oleh guru dalam mengembangkan aktivitas kegiatan inti antara lain menuliskan langkah-langkah secara mendetail karena materi luas, siswa yang kurang aktif seperti dalam kegiatan bertanya sehingga sulit mengukur ketercapaian siswa, kesulitan dalam menghidupkan suasana kelas, dan sarana pendukung tidak ada.

Pertanyaan terakhir pada bagian kedua angket ini ialah tentang pengembangan strategi menutup pembelajaran. Menurut guru menarik kesimpulan pada akhir pembelajaran perlu karena untuk mengecek daya ingat siswa, dan keseriusan dalam mengikuti pembelajaran. Pendapat lainnya menyatakan kegiatan menarik kesimpulan penting untuk siswa agar mengetahui gagasan pokok dari materi yang harus dicapai. Strategi guru dalam mengembangkan kegiatan menarik kesimpulan adalah dengan menuliskan kesimpulan di papan tulis, memberikan pertanyaan kepada siswa, dan memberikan kuis. Sedangkan apabila alokasi waktu yang direncanakan untuk kegiatan menarik kesimpulan ternyata tidak sesuai maka tindakan yang dilakukan oleh guru di kota Merauke antara lain, bersama-sama siswa membuat kesimpulan secara lisan, memberikan tugas kepada siswa untuk membuat kesimpulan di rumah, dan pendapat terbanyak menyatakan memberikan kegiatan tersebut pada pertemuan berikutnya. Selain kegiatan menarik kesimpulan, menurut guru yang dapat dilakukan pada akhir pembelajaran adalah memberikan tugas, mengingatkan materi berikutnya, penilaian, dan mendengar pendapat siswa. Kesulitan yang dialami oleh guru dalam mengembangkan kegiatan menarik kesimpulan pada rencana pelaksanaan pembelajaran berdasarkan kurikulum 2013 antara lain mengatur waktu dan kemampuan siswa untuk menerima materi dan kesulitan dalam menganalisis materi dan menentukan strategi yang efektif.

2. Pelaksanaan Kurikulum 2013

Bagian ketiga dari angket kesulitan guru dalam mengembangkan rencana pelaksanaan pembelajaran kurikulum 2013 berkaitan dengan kendala yang dialami oleh guru dalam praktik pelaksanaan kurikulum 2013. Pertanyaan tentang bagian dari kurikulum 2013 yang paling sulit dilaksanakan mendapat jawaban yang seragam dari guru yakni pada bagian penilaian khususnya pada penilaian sikap karena guru harus menilai setiap siswa. Pada kegiatan merumuskan indikator pencapaian kompetensi kesulitan yang dialami oleh guru berkaitan dengan penentuan kata kerja operasional yang sesuai. Dalam merencanakan kegiatan pembelajaran, dua langkah pendekatan saintifik yang paling sulit bagi guru adalah kegiatan menanya dan kegiatan menalar. Sedangkan kegiatan yang dianggap paling mudah adalah kegiatan mengamati.

Aspek-aspek yang dipertimbangkan oleh guru dalam menyusun penilaian adalah bentuk soal dan tingkat kesukaran. Kesulitan yang sering dialami oleh guru adalah membuat penilaian secara obyektif karena keterlibatan siswa dalam pembelajaran mengalami perubahan. Secara umum kesulitan guru adalah seluruh komponen rencana pelaksanaan pembelajaran berdasarkan kurikulum 2013, adalah komponen langkahlangkah pembelajaran yang harus dituliskan secara rinci 
dan komponen penilaian. Adapun jenis pelatihan yang diharapkan oleh guru di kota Merauke adalah pelatihan kurikulum 2013 khusus tentang penyusunan rencana pelaksanaan pembelajaran, serta harapan agar format rencana pelaksanaan pembelajaran tidak berubah-ubah setiap waktu.

\subsection{Ulasan Kesulitan Guru dalam Implementasi Kurikulum 2013}

Hasil Penelitian pada guru di kota Merauke diperoleh beberapa jenis kesulitan guru dalam mengembangkan perangkat pembelajaran berdasarkan kurikulum 2013. Secara umum komponen dari rencana pelaksanaan pembelajaran yang paling sulit dikembangkan oleh guru Di kota Merauke adalah indikator pencapaian kompetensi, pendekatan/metode/strategi pembelajaran, instrumen penilaian, remedial, dan pengayaan. Kesulitan tersebut juga dialami oleh guru-guru secara umum di Indonesia. Beberapa penelitian terdahulu di berbagai daerah di Indonesia menunjukkan bahwa guru mengalami kesulitan dalam mengembangkan perangkat pembelajaran berdasarkan kurikulum 2013.

Kesulitan guru di merauke pada kegiatan pengembangan indikator Pencapaian kompetensi dasar adalah kesulitan dalam pemilihan kata-kata operasional yang tepat. Pemilihan kata operasional untuk indikator pencapaian kompetensi memerlukan pemahaman yang mendalam dari guru tentang tuntutan kompetensi dasar, sehingga dapat menjabarkannya dalam indikatorindikator. Selain itu para guru juga merasakan kesulitan dalam menjabarkan indikator sesuai dengan tingkat kepentingannya apakah itu urgen atau penunjang. Artinya bahwa guru masih kesulitan menentukan indikator yang paling penting dari kompetensi dasar yang diberikan. Pada guru agama dan Budi Pekerti merasakan kesulitan menyusun indikator penilaian sikap agar dapat dipertanggungjawabkan. Kurikulum 2013 mengharuskan adanya indikator pencapain kompetensi dasar pada aspek sikap. Dengan demikian guru harus dapat merumuskan indikator sikap yang harus dipenuhi siswa pada kompetensi dasar. Meskipun demikian, hasil penelitian ujang dedi dkk, diperoleh bahwa implementasi kurikulum 2013 pada pembelajaran agama islam sangat efektif dalam penilaian aspek sikap, pengetahuan dan keterampilan di kota bandung (Palobo, 2018).

Kesulitan yang dialami oleh guru dalam menyusun skema pencapaian kompetensi dasar antara lain kesulitan dalam menganalisis konsep materi yang harus diselaraskan dengan pendekatan yang digunakan, tingkat kemampuan siswa yang berbeda-beda, menunjukkan bahwa perlu analisis yang mendalam terhadap materi ajar sehingga skema pencapain kompetensi dasar dapat dikembangkan dengan tepat.

Pada pengembangan kegiatan/materi apersepsi guru mengalami kesulitan pada menentukan kesesuain antara materi yang akan dipelajari dengan apersepsinya. Kegiatan apersepsi sangat penting dalam menghubungkan materi sebelumnya dengan materi yang akan dipelajari, sekaligus memberikan motivasi bagi siswa tentang pentingnya materi ajar tersebut sehingga guru perlu menyusun strategi penyampaian apersepsi agar peserta didik tetap mengaitkan setiap materi ajar yang diberikan. Selain itu kesulitan yang dialami oleh guru mengukur pengetahuan dasar peserta didik, sehingga guru kesulitan dalam mengaitkan setiap meteri ajar apabila kemampuan siswa tentang materi sebelumnya belum diketahui secara pasti. Untuk itu guru seharusnya senantiasa memberikan penilaian diakhir pembelajaran, sehingga kemampuan peserta didik tentang materi sebelumnya dapat diketahui.

Kegiatan inti dalam rencana pelaksanaan pembelajaran menjadi bagian utama dalam suatu proses belajar mengajar di kelas. Kesulitan yang dialami oleh guru di Merauke dalam mengembangkan aktivitas kegiatan inti ialah pada menuliskan langkah-langkah secara mendetail karena materi luas. Guru berpendapat bahwa materi ajar yang luas sulit untuk dibahasakan dalam langkah-langkah pembelajaran inti. Kesulitan lainya ialah dalam mengembangakan kegiatan pembelajaran inti yang mampu menghidupkan suasana kelas. Hal tersebut secara umum merupakan bagian yang sulit bagi guru karena diperlukan pemilihan metode pembelajaran yang tepat sehingga suasana pembelajaran inti yang diharapkan oleh guru dapat tercapai.

Menurut guru kesulitan terbesar dalam merancang kegiatan menarik kesimpulan pada rencana pelaksanaan pembelajaran berdasarkan kurikulum 2013 adalah mengatur waktu sehingga kegiatan menarik kesimpulan dapat dilaksanakan. Umumnya kegiatan menarik kesimpulan tidak dilaksanakan dengan maksimal karena kegiatannya dilaksanakan setelah waktu pembelajaran selesai. Sehingga pengaturan waktu dalam rencana pelaksanaan pembelajaran perlu diperhitungkan dengan matang oleh guru, tidak hanya sekedar dituliskan tanpa memperhatikan kemungkinan tidak sesuai dengan pelaksanaannya. Selain itu para guru juga merasa kesulitan menentukan strategi yang efektif dalam kegiatan menarik kesimpulan.

Selain kegiatan menyusun perangkat pembelajaran, penelitian ini juga menggali kesulitan guru dalam menerapkan kurikulum 2013 sesuai dengan rencana pelaksanaan pembelajaran. Dalam merencanakan kegiatan pembelajaran, dua langkah pendekatan saintifik yang paling sulit bagi guru adalah kegaiatan menanya dan kegiatan menalar. Sedangkan kegiatan yang dianggap paling mudah adalah kegiatan mengamati. Hasil ini sesuai dengan penelitian said darnius bahwa sebagian besar guru dalam kurikulum 2103 masih mengalami kesulitan dalam menerapkan pendekatan saintifik (Darnius, 2016). Hal tersebut menunjukkan bahwa guru masih perlu diberikan pembimbingan dalam pelaksanaan pendekatan saintifik. Sesuai dengan hasil penelitian gede widayana bahwa guru-guru sekolah kejuruan di kabupaten Kintamani saat ini terkait dengan kemampuan untuk menerapkan Kurikulum 2013 sesuai dengan tugasnya, belum memahami sifat dari kurikulum 
di Indonesia 2013, kurangnya kapasitas dan keterampilan guru di Indonesia menerjemahkan visi dan misi dari kurikulum di Indonesia 2013, karena kurangnya pelatihan yang memadai (Widayana, 2017).

Kesulitan lain yang dialami guru di kota Merauke adalah dalam menyusun penilaian. Hasil ini sesuai dengan penelitian utami ningsih dan sumardi yang menyatakan bahwa kesulitan utama guru matematika di SMP Negeri 12 Surakarta pada penerapan kurikulum 2013 yaitu tentang penilaian, buku pegangan dan kemampuan setiap siswa (Ningsih and Sumardi, 2014). Guru-guru di kota Merauke juga berharap agar format rencana pelaksanaan pembelajaran tidak terus berubah setiap saat karena menyulitkan guru. Perubahan kurikulum yang dilaksanakan semestinya memiliki dasar-dasar yang kuat serta perencanaan yang matang, sehingga tidak membingungkan para pengambil kebijakan pendidikan dan guru di daerah (Uce, 2016).

\section{KESIMPULAN}

Berdasarkan hasil penelitian diperoleh Jenis-jenis kesulitan yang dialami oleh guru di kota Merauke dalam mengembangkan perangkat pembelajaran berdasarkan kurikulum 2013 adalah kesulitan pengembangan indikator pencapaian kompetensi, kesulian penyusunan skema pencapaian kompetensi dasar, kesulitan pengembangan kegiatan apersepsi, kesulitan pengembangan aktivitas kegiatan inti, kesulitan perancangan kegiatan menarik kesimpulan, dan kesulitan penyusunan penilaian.

\section{SARAN}

Peneliti menyerankan kepada pemerintah untuk lebih memeperhatikan kesulitan yang dialami oleh guru dalam implementasi kurikulum 2013 dan memberikan kebijakan untuk mengatasi kesulitan tersebut. Serta bagi para guru untuk tetap meningkatkan kompetensi dan keahlian agar dapat mengatasi kesulitan dan kendala yang dialami dalam melaksanakan tugas.

\section{DAFTAR PUSTAKA}

8.

Ahmad, S. 2013 'Problematika Kurikulum 2013 dan Kepemimpinan Instruksional Kepala Sekolah', Jurnal pencerahan, 8(2), pp. 98-108.

Cheung, A. C. . and Wong, P. . 2016) 'Factors Affecting the Implementation of Curriculum Reform in Hong Kong: Key Findings from a Large-Scale Survey Study', Internasional Journal of Educational Management, 26(1), pp. 152-165.

Darnius, S. 2016 'Identifikasi Kesulitan Guru Dalam Mengimplementasikan Kurikulum 2013 dengan Pendekatan Saintifik di Kelas Tinggi Gugus Mangga Kecamatan Jaya Baru Banda Aceh', Jurnal Pesona Dasar, 2(4), pp. 40-48.

DiMartino, J., Castameda, A. and Miles, S. 2007 Authentic Assessment. Principal's Research Riview. New York: Springer.
Eraslan, A. 2013. 'Teachers Reflections on the Implementation of the New Elementary School Mathematics Curriculum in Turkey', HU Journal of Education, 28(2), pp. 152-165.

Gulikers, J. T. ., Bastiaens, T. . and Kirschner, P. . 2004 'A Five-Dimensional Framework for Authentic Assessment', Educational Technology Research and Development, 52(3), pp. 67-86.

I. Krisdiana, D. A. and Setiansyah, R. K. 2014. 'Analisis Kesulitan yang dihadapi oleh guru dan peserta didik sekolah menengah pertama dalam implementasi kurikulum 2013 pada mata pelajaran matematika (Studi Kasus Eks-Karisidenan Madiun)', Jurnal Ilmiah Pendidikan Matematika, 3(1), pp. 1-10.

Indonesia, M. P. dan K. R. 2013. 'Peraturan Menteri Pendidikan dan Kebudayaan Nomor 81 Tahun 2013 tentang Pelaksanaan Penilaian'.

Indonesia, P. R. 2005. 'UU No. 142005 tentang Guru dan Dosen'.

Lumadi, M. 2013. 'Challenges Besetting Teachers in Classroom Assessment: An Exploratory Perpective', Journal of Social Science, 34(3), pp. 211-221.

Maisyaroh, W. et al. 2014 'Masalah guru dalam implementasi kurikulum 2013 dan kerangka model supervisi pengajaran', Manajemen Pendidikan, 24(3), pp. 213-220.

Ningsih, U. and Sumardi. 2014. Analisis Kesulitan Guru Matematika Kelas VII dalam Menerapkan Kurikulum 2013 di SMP N 12 Surakarta. Universitas Muhammadyah Surakarta.

Palobo, M. 2018. 'Analysis of Teachers' Difficulties on Developing Curriculum 2013 Lesson Plans', in 1st International Conference on Social Sciences (ICSS 2018). Atlantis Perss, pp. 1319-1324. Available at: https://www.atlantis-press.com/proceedings/icss$18 / 25904025$.

Palobo, M. and Tembang, Y. 2019. 'Analisis Kualitas Rancangan Penelitian Tindakan Kelas Guru', MAGISTRA: Jurnal Keguruan dan Ilmu Pendidikan, 6(2), pp. 119-128.

Puskurbuk. 2012 Pengeseran Paradigma Belajar Abad 21., http://www.puskurbuk.

Surya., O. L. A., Witjaksono, M. and Utomo, S. H. 2016 'Analisis Kesulitan guru dalam implementasi kurikulum 2013 mata pelajaran ekonomi dan upaya mengatasinya', in National Conference On Economic Education, pp. 1182-1190.

Uce, L. 2016 'Realitas Aktual Praksis Kurikulum: Analisis terhadap KBK, KTSP, dan Kurikulum 2013', Jurnal Ilmiah DIDAKTIKA, 6(2), pp. 216229.

Widayana, G. 2017. 'SMK Teacher Quality Improvement Through Training Development And Packaging Device Based Learning Curriculum 2013.', in Atlantis press, Advances in Social Science, Education and Humanities Research, Vol (116), International Conference On Vocational 
Education And Training (ICOVET 2017)., pp. 1322-1330.
UCAPAN TERIMA KASIH

Disampaikan terima kasih kepada direktuk riset dan pengabdian pad masyarakat RISTEKDIKTI yang telah membiayai penelitian ini serta seluruh guru-guru di kota merauke yang menjadi subyek penelitian 